\title{
From ideology to metametanarrative
}

\section{(addendum to Consuming antinatalism in social media)}

George Rossolatos MSc, MBA, PhD

email: georgerossolatos123@gmail.com

Despite Lyotard's proclaimed end of metanarratives in a post-modern predicament, metanarratives appear to be making a comeback. This is the case for antinatalism, a relatively recent ideological formation or moral philosophical perspective that has spawned a new social movement with an active presence in social media. The organizational and structural aspects of NSMs render them amenable to being labeled as 'post-modern'. In this context, the emergence of ideologies as moral philosophies, such as antinatalism, loom like an outsider, or like a retro fissure in a plastic canvass. The reason is that antinatalism shares the holistic, fundamentalist and totalizing discursive traits of modernist metanarratives that were heralded by Lyotard (1984) as being outmoded in a post-modern condition. Yet, this metanarrative is also different in fundamental aspects from traditional metanarratives. These aspects pertain to its rhetorical self-reflexivity and to its pre-occupation with rooting the propounded arguments in empirical particulars, rather than in a metaphysical or transcendentalist realm. This new form of metanarrative I call metametanarrative as it constitutes a philosophical regression, so to speak, in a pre post-modernist cultural milieu.

The cultural terrain of this metametanararrative's emergence is marked by social media enabled NSMs whose members negotiate the meaning of ideologies in all sorts of manners that differ from the modernist era, thus engaging actively not only in value cocreation (Harwood \& Garry, 2014; Dhaka, 2015) and product co-creation (He \& Yan, 2015), but in values (as axiological components) co-creation. 
Benatar's (2015) antinatalist philosophy appears to be sharing the same characteristics as traditional philosophical metanarratives. The concept of metanarrative and its (ab)uses as a principle of textuality buttressing ideologies, as a social trope, and as an ethotic blueprint animating social action, was coined by Jean-Francois Lyotard (1984) in his path-breaking The Postmodern Condition.

For Lyotard, the metanarratives of modernity, such as Hegel's Phenomenology of Spirit, constitute self-referential grand narratives whose claims and propositions regarding truth, value and the ends of man rely on the very premises of self-enclosed systems. A philosophical system as metanarrative is a totalizing discourse whose individual premises depend on the work as a whole. This type of speculative metanarratives is complemented by emancipatory metanarratives that begin for Lyotard with the French Revolution in 1789 (Malpas, 2003). As an example of a moral philosophical system that abides by the definition of emancipatory metanarrative we may cite Kant's (2002) Groundwork for the Metaphysics of Morals that posits free will as acting out of duty in line with moral laws. Acting morally is conditioned by a totalizing discourse as what Kant (2002) calls the 'kingdom of ends'. It is within this metaphorical kingdom that every man is viewed potentially as the legislator of morally binding maxims. Metanarratives concern not only epistemological aspects, but also fundamental existential and ontological issues. Such discursive forms, by dint of their highly systematic composition and the inter-dependence of the premises that comprise them constitute totalizing discourses.

Metanarratives, though, are not the sole province of philosophical systems. They are also couched in mythical discursive articulations, as in the Christian account of the origin of man as fallen from a metaphorical utopian space called Eden due to having transgressed the word of god. The territories where both theological and philosophical metanarratives 
converge consist in their addressing fundamental aspects of human existence and in their pragmatic function as blueprints for legitimating social action.

Furthermore, both types of discourse converge on their more or less rhetorical configuration. The theological discourse employs parables which are equivalent to long metaphors, while the aforementioned Kantian discourse employs theologically inspired metaphors such as the 'kingdom of ends' (as a paradigmatic shift whereby God was replaced by Reason). Even more importantly, according to Lyotard's (1984) initial exposition, metanarratives constitute sources for legitimating social action, by fuelling ideologies and their respective axiologies. For example, despite the mythical status of the theological discourse, it is regularly evoked by those who endorse its premises as the reason why man is by nature sinful. The subscription to this fabular construal as a major premise of a moral system wherein the moral category of $\sin$ is embedded has exerted a paramount influence on fundamental aspects of legal systems, as well as animated popular culture.

Finally, metanarratives are differentiated from ordinary empirical narratives and consumer stories by dint of their totalizing, universalistic character and their constituting blueprints for edifying ideologies as belief systems that are directly proportional to what social actions are undertaken and how such actions and their outcomes are interpreted and evaluated. In a nutshell, the philosophical or theological premises of metanarratives furnish criteria for legitimating actions. Insofar as metanarratives are evinced as belief-systems, they are indispensable in the formation of ideologies. Although the post-modern turn was identified with a distancing from metanarratives and grand ideologies (e.g. sedimented political discourses about left/right), as well as with a substitution of grand ideologies with situated and ephemeral discursive formations, such as the communal discourses of brandrelated fandoms (either online or offline), but also with a pragmatic, rather than metaphysical orientation, metanarratives can hardly be said to have lost their pertinence. They have 
somehow transmuted while adapting to the exigencies of a fast moving ideological landscape. This intellectual arena has favored the emergence of new ideologemes that bear considerable resemblance to metanarratives, yet whose mode of articulation takes direct notice of an underlying rhetoricity, rather than seeking to essentialize narrative constructs as was the case with Kant's evocative transportation to a 'kingdom of ends' (or with A.Smith's employment of the 'invisible hand' metaphor while seeking to legitimate in his metanarrative how markets attain to regulate themselves).

These ideologemes I call metametanarratives, insofar as they lie in a liminal zone between modernity and post-modernity. Metametanarratives do raise claims about fundamental existential and moral issues that are conducive to the formation of belief systems that animate ideologies which in turn prescribe routes for social action. However, their narrative articulation is evinced as a constant self-reflexive interplay with rhetoricity as condition of textuality. This is the case with the philosophy of antinatalism.

Furthermore, metametanarratives differ from modernist metanarratives in terms of their level of systematicity. Whereas modernist metanarratives (see Lyotard, 1984) constitute self-contained systems of thought that are systematically organized in interdependent layers of major and minor premises, metametanarratives are premised on not necessarily interdependent arguments whose major premises are posited axiomatically as slogans or as punchlines (akin to social media memes such as Occupy Wall Street movement's 'We are the 99\%') . They are more intuitively appealing and resonant with pathos rather than logos. Metametanarratives seek to consolidate imaginary (Anderson, 1991) and affective communities by appealing to their emotions. "As we know from many studies on the impact of ideologies through persuasive rhetoric, ideologies are also connected to and make use of emotions" (Wodak, 2006, 11). "This shared responsiveness to gestures and signals permits emotional contagion to be stimulated and manipulated in solidarity rituals" (Gordon, 1986, 
138). Finally, metametanarratives do not constitute dogmas, but due to their fuzzily formalized (Van Dijk, 1998) nature and the ability of their clientele to negotiate, interpret and misinterpret their premises, ongoing discourses that deploy in social media.

\section{References}

Anderson, B. R. O. G. (1991). Imagined communities: Reflections on the origin and spread of nationalism. New York: Verso.

Benatar, David (2015). Better never to have been: the harm of coming into existence. Oxford: Oxford University Press.

Dhaka, Sunishtha (2015). Co-creation: literature review and research issues. International Journal of Research, 3(2), 20-37.

Gordon, Steven L. (1986). Micro-sociological theories of emotion. In S.N.Eisenstadt \& H.J.Helle (Eds.), Micro-sociological theory: perspectives on sociological theory vol. 2 (pp. 133-147). London: Sage.

Harwood, Tracy \& Tony Garry (2014). Co-creation and ambiguous ownership within virtual communities: the case of the Machinima community. Journal of Consumer Behaviour, 13, 148-156.

Kant, Immanuel (2002). Groundwork for the metaphysics of morals. New Haven: Yale.

Lyotard, Jean-Francois (1984). The postmodern condition: a report on knowledge. Manchester: Manchester University Press.

Malpas, Simon (2003). Jean-Francois Lyotard. London: Routledge.

Van Dijk, Teun (1998). Ideology: A multidisciplinary approach. London: Sage.

Wodak, Ruth (2006). Images in/and news in a globalised world: Introductory thoughts. In Inger Lassen, Jeanne Strunck \& Torben Vestergaard (Eds.), Mediating ideology in text and image: ten critical studies (pp. 1-18). Amsterdam: John Benjamins. 